\title{
AS CONCEPÇÕES LOGICA E GRAMATICAL DA ORAÇÃO
}

\author{
Felipe Jorge
}

A oração tem sido definida pelos gramáticos ou como expressão de um juízo ou como conjunto de palavras com sentido completo. No primeiro caso, por influência da Lógica tradicional, que define a proposição como o enunciado verbal do juízo; no segundo, por influência da tradição clássica, que ascende ao velho Dionísio de Trácia.

Examinemos as duas definições.

$1^{a}$ ) Oração é a expressão de um juízo.

Emitimos um juízo quando afirmamos a conveniência ou desconveniência entre duas idéias. Exemplos:

$O$ homem é racional.

$O$ homem não é máquina.

No primeiro, afirmamos que a idéia de racional convém à de homem, porque o homem é realmente racional; no segundo, afirmamos que a idéia de máquina não convém à de homem, porque o homem não é realmente máquina. Em ambos, formulamos um juízo. Isto nos permite definir o juízo como a afirmação da conveniência ou desconveniência entre duas idéias. Entretanto, é mais comum dizer que o juízo consiste em afirmar ou negar uma relação entre duas idéias ou simplesmente em afirmar ou negar uma relação. Preferimos ser mais rigorosos e considerar o juízo como a afirmação de uma relação entre dois objetos do pensamento e não entre duas idéias. Por quê? Porque o juízo não incide nas idéias que temos das coisas, mas nas próprias coisas. Quando dizemos, por exemplo, caqui é delicioso, o nosso juízo não recai na idéia que temos do caqui, mas no próprio caqui.

De qualquer modo, todo juízo é uma afirmação, seja da conveniência ou desconveniência entre duas idéias, seja da relação entre duas idéias ou entre do's objetos do pensamento. Ora, se todo juízo é uma afirmação e se toda oração é a expressão de um juízo, concluímos facilmente que esta definição só convém a uma classe de orações: as declarativas ou enuncintivas. Aceita tal definição, os exemplos seguintes: 


\begin{abstract}
Quem inventou a pólvora?
Não atireis a primeira pedra.

$O$ pão nosso de cada dia nos dai hoje.

A terra lhe seja leve!
\end{abstract}

não constituem logicamente orações, porque não exprimem juízos. Com efeito, em nenhum deles se faz uma afirmação. O primeiro encerra uma pergunta, o segundo exprime uma ordem, o terceiro, uma súplica, o quarto, um desejo. Ora, em Lógica, pergunta, ordem, súplica, desejo não são juízos. Entretanto, gramáticos eminentes aceitam a definição acima e ilogicamente dividem as orações, quanto ao sentido, em declarativos, interrogativas, imperativas, optativas.

Mas não é só. Nem sempre há perfeito paralelismo entre a estrutura da proposição, definida na Lógica tradicional como o enunciado verbal do juízo ou expressão verbal do juízo, e a estrutura da oração, definida pelos gramáticos como a expressão de um juízo. No exemplo: Os heróis que tombaram no campo da luta eram soldados do $3^{\circ}$ exército, há uma só proposição para a Lógica, uma vez que o sujeito lógico é os heróis que tombaram no campo da luta; mas, para os gramáticos, são duas as orações: os heróis eram soldados do $3^{\circ}$ exército, principal; e que tombaram no campo da luta, subordinada à principal, adjetiva restritiva .

2ạ) Oração é um conjunto de palavras com sentido completo.

Esta definição é igualmente vulnerável.

Nem sempre a oração é conjunto de palavras; às vezes se reduz a uma só palavra. Exemplos:

\title{
Oremos \\ Saia.
}

Anoitece.

Por dependerem de outra oração, as subordinadas - substantivas, adjetivas e adverbiais - não podem logicamente ter sentido completo. Neste período de Alexandre Herculano, extraído de Eurico,o presbitero: Os soldados que seguiam a bandeira de Teodemiro tinham-se abalado para o combate apenas viram os esquadrões de Ruderico, as orações subordinadas:

\author{
que seguiam a bandeira de Teodemiro \\ apenas viram \\ partir os esquadrões de Ruderico
}

não têm sentido, completo. A primeira por exprimir uma qualidade do antecedente soldados (oração subordinada adjetiva restritiva); a segunda, uma circunstância de tempo de tinham abalado (oração subor- 
dinada adverbial temporal); a terceira, o objeto de viram (oração subordinada substantiva objetiva direta)

Alegar-se-á que a definição acima só se aplica às orações absolutas e principais. Nada mais infundado. Em primeiro lugar, pode haver uma definição para as orações absolutas e principais e outra para as crações subordinadas; em segundo, se as orações absolutas têm sentido em si mesma, nem todas as chamadas principais encerram sentido completo. No exemplo de Alencar: $O$ que sei é que te amo, pode a principal ( $o$ é) prescindir das subordinadas para ter sentido?

Como explicar tais divergências entre as definições (oração é a expressão de um juízo, oração é um conjunto de palavras com sentido completo) e o seu objeto, isto é, a oração?

Aqui bate o ponto. Gramáticos e professores já encanecidos ou ainda pouco experientes, aqueles nas suas obras e estes nas suas aulas, costumam iniciar a exposição da matéria com uma das definições dadas ou com outra de cunho mais ou menos pessoal, para depois abandoná-la e esquecê-la definitivamente e só considerar a oração, para todos os efeitos, em função dos seus termos essenciais (sujeito e predicado) .

Dessa concepção puramente formal, baseada na participaçāo sujeito-predicado, podemos apontar duas consequiências danosas para a análise sintática, que muito contribuem para o seu descrédito e justificam, de algum modo, a velha crítica de mestre Silva Ramos, isto e, de que a análise lógica, como era chamada no seu tempo a análise sintática, muitas vezes nada tem de lógica:

1 a) tanto são orações as que encerram sentido completo, como as subordinadas — substantivas, adjetivas e adverbiais —, sem sentido em si mesmas;

2a) quando o sujeito, o objeto, o predicativo, o complemento nominal, o adjunto adnominal, o adjunto adverbial são expressos por meio de orações - orações subjetivas, objetivas predicativas, completivas nominais, adjetiva e adverbiais —, fica a oração regente mutilada. 